\title{
Genetic variability of wild populations of Leporinus elongatus in the São Domingos River - MS Brazil: a preliminary view on the construction of the hydroelectric plant
}

\section{Variabilidade genética de populações naturais de Leporinus elongatus do rio São Domingos, MS - Brasil: uma visão preliminar à construção da usina hidrelétrica}

\author{
Ricardo Pereira Ribeiro'; Maria del Pilar Rodriguez-Rodriguez²; \\ Darci Carlos Fornari ${ }^{3}$; Gilmar Baumgartner ${ }^{4}$; Dirceu Baumgartner ${ }^{5}$; \\ Felipe Pinheiro de Souza ${ }^{5}$; Pedro Luiz de Castro ${ }^{6}$; Angela Rocio Poveda-Parra ${ }^{7}$; \\ Elenice Souza dos Reis Goes ${ }^{8}$; Nelson Mauricio Lopera-Barrero ${ }^{9^{*}}$
}

\begin{abstract}
Most of the electricity used in Brazil comes from hydroelectric plants, mainly due to the great availability of its water resources. However, the construction of these plants denotes serious problems related to migration of native fish and the genetic conservation of stocks. Current study evaluates two wild population of Leporinus elongatus (piapara) located downstream (Population A - PopA) and upstream (Population B - PopB) of the Cachoeira Branca before the construction of the São Domingos hydroelectric plant (HPP) in the Mato Grosso do Sul State, Brazil. Thirty samples from caudal fins were collected and analyzed for each population. Eighty-nine fragments, including 72 polymorphic ones $(80.9 \%)$, were analyzed. Low fragments (less than 0.100 ) in both populations (PopA $=2$ and PopB $=3$ ) were identified. Nine fixed fragments (frequency 1.000) (PopA $=3$ and $\mathrm{PopB}=6$ ), and four exclusive fragments (PopA $=3$ and $\mathrm{PopB}=1)$ were also reported. The genetic variability within populations, calculated by Shannon Index and by percentage of polymorphic fragments, indicated high rates of intrapopulation variability ( $\mathrm{PopA}=0.309$ and $61.80 \%$ and $\mathrm{PopB}=0.392$ and $71.90 \%$, respectively). Genetic distance and identity rates ( 0.089 and 0.915 , respectively) were different between populations, whilst AMOVA showed that most variations lie within the populations and not between them. Fst and Nm rates showed moderate genetic differentiation with low numbers of migrants. Results reveal populations with high intra-population genetic variability and genetic differentiation, with low gene flow. The passage
\end{abstract}

\footnotetext{
${ }^{1}$ Prof. Dr., Departamento de Zootecnia, Programa de Pós-Graduação em Zootecnia, Universidade Estadual de Maringá, UEM, Maringá, PR, Brasil. E-mail: rpribeiro@uem.br

${ }^{2} \mathrm{Dr}^{\mathrm{a}}$ Pesquisadora, Universidade Federal dos Vales de Jequitinhonha e Mucuri, UFVJM, Diamantina, MG, Brasil. E-mail: rodrigpilar@gmail.com

3 Diretor Executivo, Genetic Fish Rise, Primavera do Norte, Sorriso, MT, Brasil. E-mail: darci.peixegen@gmail.com

${ }^{4}$ Profs. Drs., Universidade Estadual do Oeste do Paraná, UNIOESTE, Toledo, PR, Brasil. E-mail: gilmar_baum@yahoo.com.br; baum.d@hotmail.com

5 Discente, Programa de Pós-Graduação em Ciência Animal, Universidade Estadual de Londrina, UEL, Londrina, PR, Brasil. E-mail: felipeps1991@gmail.com

${ }^{6}$ Discente, Programa de Pós-Graduação em Zootecnia, UEM, Maringá, PR, Brasil. E-mail: pedrocastro.zoo@hotmail.com,

${ }^{7}$ Pós-Doutoranda, Dept ${ }^{\circ}$ de Zootecnia, UEL, Londrina, PR, Brasil. E-mail: angelapovedaparra@hotmail.com

${ }^{8}$ Pós-Doutoranda, Dept ${ }^{\circ}$ de Zootecnia, UEM, Maringá, PR, Brasil. E-mail: elenicesreis@yahoo.com.br

${ }^{9}$ Prof. Dr., Departamento de Zootecnia, Programa de Pós-Graduação em Ciência Animal, UEL, Londrina, PR, Brasil. E-mail: nmlopera@uel.br

* Author for correspondence
} 
ladders of São Domingos HPP should control fish transposition to preserve genetic variability. Key words: Fish. Genetic conservation. Genetic diversity. Hydroelectric plant. Piapara.

\title{
Resumo
}

\begin{abstract}
A maior parte da energia elétrica utilizada no Brasil provém de usinas hidrelétricas, devido principalmente à grande disponibilidade de recursos hídricos. Contudo, a construção dessas usinas pode representar graves problemas relacionados com a migração de peixes nativos e com a conservação genética dessas populações. O objetivo do presente trabalho foi avaliar duas populações naturais de Piapara (Leporinus elongatus) localizadas à jusante (População A - PopA) e montante (População B - PopB) da Cachoeira Branca no período anterior à construção da usina hidrelétrica (UHE) São Domingos, Mato Grosso do Sul - Brasil. Trinta amostras de nadadeira caudal foram coletadas e analisadas para cada população. No total, foram observados 89 fragmentos dos quais 72 foram polimórficos $(80,9 \%)$. Foram identificados fragmentos de baixa frequência (menor que 0,100$)$ em ambas as populações (PopA $=2$ e PopB $=3$ ). Nove fragmentos fixados (frequência de 1,000) $(\mathrm{PopA}=6$ e PopB $=3)$ e quatro fragmentos exclusivos $($ PopA $=3$ e PopB $=1)$ também foram observados. A variabilidade genética dentro das populações, calculada através do índice de Shannon e pela porcentagem de fragmentos polimórficos mostrou altos valores de variabilidade intra-populacional (PopA $=0,309$ e 61,80\% e PopB $=0,392$ e 71,90\%, respectivamente). Os valores de distância e a identidade genética $(0,089$ e 0,915 , respectivamente) mostraram diferenciação entre as populações e a AMOVA mostrou que a maior parte da variação está dentro de cada população e não entre elas. Os valores de Fst e Nm mostraram moderada diferenciação genética com baixo número de migrantes. Conclui-se que as populações apresentaram alta variabilidade genética intra-populacional e diferenciação genética entre si, com baixo fluxo gênico. Para preservar a variabilidade genética será necessário que as escadas de transposição da UHE São Domingos realizem uma transposição controlada dos peixes.
\end{abstract}

Palavras-chave: Conservação genética. Diversidade genética. Peixe. Piapara. Usina hidrelétrica.

\section{Introduction}

Most electric energy produced in Brazil comes from hydroelectric plants (HPP) since they are low-cost, sustainable sources (BRASIL, 2015). However, their deployment and functioning brings about several environmental issues (FONTES, 2011) due to the changes caused by their construction. For instance, fish population structure is modified due to migration inhibition of native species by dam building (AGOSTINHO et al., 2007; ANDRADE, 2009; LIMA, 2015).

Transposition mechanisms in dams permit the passage of fish between areas downstream and upstream, although most mechanisms (ladders and lifts) are employed only for ascending displacements. However, fish mortality has been reported during such deployment (SIROL; BRITTO, 2006). Little is actually known with regard to the effects of HPP on the movement and behavior of fish with habitats in the dam area (SUZUKI, 2014) and information on fish communities in the dam's immediate area is highly relevant for the deployment of less impacting procedures (FONTES, 2011).

The species Leporinus elongatus (Valenciennes, 1850), order Characiformes, family Anostomidae, subfamily Anostominae (AGOSTINHO et al., 1997), is a mid-sized, long-distance migration fish which is present in the basins of the Paraná, São Francisco and Amazon Rivers (AGOSTINHO et al., 2007). According to Luiz et al. (2003), the damming of water courses generates deleterious effects on fish populations and may cause the local or regional extinction of endemic species. Excessive fishing and pollution cause the same effects on populations of migratory fish (AGOSTINHO et al., 2007; ANDRADE, 2009). The maintenance of genetic variability in wild stocks is relevant for the adaptability and survival of offspring (POVH 
et al., 2008) and the strategies that assess genetic differentiation are important to analyze conditions in which variability is lost (GOMES et al., 2013; MARTELETO, 2015). Molecular markers may be largely used to identify the animals' genetic characteristics, such as monitoring genetic variability (LOPERA-BARRERO, 2009; GASQUES et al., 2013).

Research with dominant molecular markers has produced satisfactory results in wild populations of L. elongatus caught in transposition ladders of HPP (PAULA, 2006; RAMOS et al., 2012). Further, other recent research works demonstrated the efficiency of these techniques in restocking programs or in broodstocks of other native species (ALMEIDA et al., 2013; GOMES et al., 2011, 2013; JACOMETO et al., 2010; LOPERA-BARRERO et al., 2010). Due to easy techniques and extensive polymorphism, markers are highly common in research on neotropical fish (HILSDORF, 2013).

Current assay evaluates the genetic variability of two populations of L. elongatus downstream and upstream the Cachoeira Branca (the axis of the dam) before the construction of the HPP.

\section{Materials and Methods}

Generator 1 of the São Domingos HPP was built in the municipalities of Água Clara and Ribas do Rio Pardo, Mato Grosso do Sul State (MS), Brazil, on the Verde River and started functioning in June 2013. The impounding of the reservoir started on the $5^{\text {th }}$ October 2012 and ended on the $9^{\text {th }}$ January 2013, flooding a section of the Araras, São Domingos and Verde Rivers (ELETROBRASELETROSUL, 2014). The dam was also built on the axis of the Cachoeira Branca, which, prior to the construction of the dam, consisted of two waterfalls constituting a physical barrier for the migration of fish. The caudal fins of L. elongatus were collected between November 2010 and March 2011 (one year before the building of the HPP) at two sites, namely, downstream (population A - PopA) and upstream (population B - PopB) of the Cachoeira Branca. Sixty samples (30 from each population) were collected.

DNA was extracted according to methodology by Lopera-Barrero et al. (2008), or rather, $550 \mu \mathrm{L}$ lysis buffer $\left(50 \mathrm{mmol} \mathrm{L}^{-1}\right.$ Tris- $\mathrm{HCl}, 50 \mathrm{mmol} \mathrm{L}^{-1}$ EDTA, $100 \mathrm{mmol} \mathrm{L}^{-1} \mathrm{NaCl}$ and $1 \% \mathrm{SDS}$ ) and $7 \mu \mathrm{L}$ proteinase $\mathrm{K}\left(200 \mathrm{mg} \mu \mathrm{L}^{-1}\right)$ were added to microtubes with the fins. The material was incubated in a warm bath at $50^{\circ} \mathrm{C}$ for 12 hours. DNA was precipitated with 600 $\mu \mathrm{L}$ of $\mathrm{NaCl}$ solution $\left(5 \mathrm{~mol} \mathrm{~L}^{-1}\right)$ and centrifuged for $10 \mathrm{~min}$ at $12.000 \mathrm{~g}$. The supernatant with DNA was transferred to $800 \mu \mathrm{L}$ microtube, precipitated with $700 \mu \mathrm{L}$ absolute ethyl alcohol and incubated for 1 hour at $-20^{\circ} \mathrm{C}$. DNA was then centrifuged, washed in $700 \mu \mathrm{L}$ ethyl alcohol $70 \%$, suspended in $85 \mu \mathrm{L}$ TE buffer $\left(10 \mathrm{mmol} \mathrm{L}^{-1}\right.$ Tris $\mathrm{pH} 8$ and $1 \mathrm{mmol} \mathrm{L}^{-1}$ EDTA) and treated with $7 \mu \mathrm{L}$ RNAse $\left(30 \mathrm{mg} \mathrm{mL}^{-1}\right)$ in a warm bath at $37^{\circ} \mathrm{C}$ for 1 hour. The material was then stored in a freezer at $-20^{\circ} \mathrm{C}$.

DNA was quantified in a spectrophotometer (Shimadzu Corporation, Kyoto, Japan) with $260 \mathrm{~nm}$ absorbance. Samples were diluted for a concentration of $10 \mathrm{ng} \mu \mathrm{L}^{-1}$. Agarose gel electrophoresis $1 \%$ was performed to guarantee the quality of extracted DNA, by buffer TBE $1 \mathrm{X}\left(500 \mathrm{mmol} \mathrm{L}^{-1}\right.$ Tris- $\mathrm{HCl}$, $60 \mathrm{mmol} \mathrm{L}^{-1}$ boric acid and $83 \mathrm{mmol} \mathrm{L}^{-1}$ EDTA), for 1 hour, at 70 volts. Amplification conditions were based on procedures by Williams et al. (1990), with modifications. DNA was amplified in a $15 \mu \mathrm{L}$ reaction volume in which $1 \mathrm{X}$ Tris- $\mathrm{KCl}, 2 \mathrm{mmol} \mathrm{L}^{-1}$ de $\mathrm{MgCl} 2,0.46 \mu \mathrm{mol} \mathrm{L}{ }^{-1}$ starter, $0.2 \mathrm{mmol} \mathrm{L}^{-1}$ of each dNTP, one Platinum Taq DNA Polymerase unit (Invitrogen, Carlsbad, USA), and 10 ng target DNA, were used as buffer.

DNA was denatured at $92^{\circ} \mathrm{C}$ for 4 min; 40 cycles were performed, each with $40 \mathrm{~s}$ denaturation at $92^{\circ} \mathrm{C} ; 1: 30$ min annealing of starter at $40^{\circ} \mathrm{C} ; 2 \mathrm{~min}$ for extension at $72^{\circ} \mathrm{C}$; followed by a final extension at $72^{\circ} \mathrm{C}$ for $5 \mathrm{~min}$. Reaction were amplified in an Eppendorf MasterCycler Gradient thermocycler. Eight different 10-base starters were chosen from 
Kits OPA, OPW and OPX (Operon Technologies Ltd., Valencia, USA) with the best definition and reproducibility (Table 1 ).

Amplification products were separated by agarose gel $1.5 \%$ and $15 \mu \mathrm{L}$ of the amplified product and $2 \mu \mathrm{L}$ of the sample buffer $(40 \%$ sucrose and $0.25 \%$ bromophenol blue) were used in horizontal electrophoresis. Electrophoresis was conducted in TBE $0.5 \mathrm{X}$ buffer $\left(45 \mathrm{mmol} \mathrm{L}^{-1}\right.$ TrisBorate and $1 \mathrm{mmol} \mathrm{L}^{-1}$ EDTA) during 4 hours, at 70 volts. Quantification and amplification gels were perceived under UV radiation after exposure with ethidium bromide $\left(0.5 \mu \mathrm{g} \mathrm{mL} \mathrm{m}^{-1}\right)$ for $1 \mathrm{~h}$. The image was photographed by a Loccus Trans-illuminator L PIX (USA).

Table 1. Nucleotide Sequences of starters, percentage of pyrimidine bases $(G+C)$, number and size of amplified fragments for populations of piapara (L. elongatus) within the HPP São Domingos area.

\begin{tabular}{lcccc}
\hline Starters & Nucleotide sequences & $\mathbf{\%}(\mathbf{G + C )}$ & N. of fragments & Size of fragments (bp) \\
\hline OPA02 & 5'-TGCCGAGCTG-3' & 70 & 14 & $400-1900$ \\
OPA16 & 5'-AGCCAGCGAA-3' & 60 & 12 & $290-2100$ \\
OPW04 & 5'-CAGAAGCGGA-3' & 60 & 14 & $250-2072$ \\
OPW06 & 5'-AGGCCCGATG-3' & 70 & 16 & $540-1900$ \\
OPW19 & 5'-CAAAGCGCTC-3' & 60 & 21 & $200-2200$ \\
OPX06 & 5'-ACGCCAGAGG-3' & 70 & 12 & $300-2072$ \\
\hline Total & - & - & $\mathbf{8 9}$ & $\mathbf{2 0 0 - 2 2 0 0}$ \\
\hline
\end{tabular}

Size of fragments by amplifications was estimated by comparing to standard ladder 100 bp (Invitrogen, Carlsbad, USA). The presence or absence of identical molecular sizes was employed to build a similarity matrix based on Jaccard's similarity coefficient, coding 1 as presence of fragment and 0 as absence.

Shannon's genetic diversity index and percentage of polymorphic fragments (95\% criterion) were obtained by PopGene 1.31 (YEH et al., 1999), whilst TFPGA 1.3 (MILLER, 1997) determined genetic distance and identity (NEI, 1978) among the populations and frequency of fragments by exact text (RAYMOND; ROUSSET, 1995). Arlequin 3.0 (EXCOFFIER et al., 2005) determined the genetic differentiation by Fst (ancestry coefficient) estimates (WEIR; COCKERHAM, 1984) and for the analysis of molecular variance - AMOVA (EXCOFFIER et al., 1992). The significance of tests was verified by the randomized permutation method, with 1,000 and 10,000 permutations. The program was also employed to determine the number of migrants per generation $(\mathrm{Nm})$. The statistical significance of Fst was obtained by $\chi^{2}$ test $\left[\mathrm{c}^{2}=2 \mathrm{n}\right.$ Fst $(\mathrm{k}-1) ; \mathrm{GL}=(\mathrm{k}-1)$ (s-1)], following Workman and Niswander (1970), in which: $\mathrm{n}$ is the number of specimens in the two groups; $\mathrm{k}$ is the number of alleles; $\mathrm{s}$ is the number of groups. The greatness of genetic difference between stocks was calculated according to Wright (1978), or rather, low (Fst $=0-0.05)$; moderate $(\mathrm{Fst}=$ $0.05-0.15)$; high $(\mathrm{Fst}=0.15-0.25)$ and very high (Fst $>0.25$ ).

\section{Results and Discussion}

Six starters with the best amplification and reproductive characteristics were selected, totaling 89 fragments, including $72(80.9 \%)$ polymorphic ones. The number of fragments ranged between 12 and 21, size between 200 and 2200 bp (Table 1). In their study on L. elongatus, Ramos et al. (2012) detected a similar number of fragments varying between 8 and 22 . 
There were significant differences $(\mathrm{p}<0.05)$ in the frequency of 25 out of the 89 fragments, with low-frequency fragments (less than 0.100) reported in populations $\mathrm{A}(\mathrm{PopA}=2)$ and $\mathrm{B}(\mathrm{PopB}=3)$.
Fixed fragments (1.000 frequency) were detected in the two populations $(\mathrm{PopA}=6$ and $\mathrm{PopB}=3)$ and four exclusive fragments $(\mathrm{PopA}=3$ and $\mathrm{PopB}=1)$ (Table 2).

Table 2. Characterization, base pairs and frequency of fragments with significant rates by exact test $(\mathrm{p}<0.05)$ for populations (PopA and PopB) of Piapara (L. elongatus) within the HPP São Domingos area.

\begin{tabular}{|c|c|c|c|}
\hline \multicolumn{4}{|c|}{ OPA02 } \\
\hline $\mathrm{bp}$ & PopA & PopB & $\mathrm{p}$ \\
\hline 1700 & 0.553 & 1.000 & 0.001 \\
\hline 500 & 0.163 & --- & 0.000 \\
\hline \multicolumn{4}{|c|}{ OPA16 } \\
\hline 1400 & 0.592 & 1.000 & 0.000 \\
\hline 1250 & 0.264 & 0.717 & 0.000 \\
\hline 650 & 0.021 & 0.151 & 0.000 \\
\hline \multicolumn{4}{|c|}{ OPW04 } \\
\hline 1200 & 0.220 & --- & 0.000 \\
\hline 1050 & 0.115 & --- & 0.000 \\
\hline 300 & 0.410 & 0.804 & 0.001 \\
\hline \multicolumn{4}{|c|}{ OPW06 } \\
\hline 1350 & 1.000 & 0.471 & 0.000 \\
\hline 1250 & --- & 0.083 & 0.000 \\
\hline 1100 & 0.019 & 0.200 & 0.000 \\
\hline 1000 & 0.230 & 0.062 & 0.000 \\
\hline 900 & 1.000 & 0.337 & 0.000 \\
\hline 800 & 0.255 & 1.000 & 0.000 \\
\hline 730 & 1.000 & 0.128 & 0.000 \\
\hline 700 & 0.456 & 0.800 & 0.000 \\
\hline 580 & 1.000 & 0.367 & 0.000 \\
\hline \multicolumn{4}{|c|}{ OPW19 } \\
\hline 1900 & 0.163 & 0.629 & 0.000 \\
\hline 1250 & 1.000 & 0.585 & 0.000 \\
\hline 1100 & 1.000 & 1.000 & 0.000 \\
\hline 850 & 0.684 & 0.090 & 0.000 \\
\hline \multicolumn{4}{|c|}{ OPX06 } \\
\hline 1800 & 0.163 & 0.373 & 0.002 \\
\hline 1300 & 0.484 & 0.134 & 0.000 \\
\hline 1200 & 0.247 & 0.500 & 0.002 \\
\hline 730 & 0.225 & 0.433 & 0.004 \\
\hline
\end{tabular}

Shannon's Index of genetic diversity and the percentage of polymorphic fragments were higher in PopA (0.392 and $71.9 \%$, respectively) than in PopB (0.309 and 61.8\%, respectively) (Table
3). Above results coupled to exclusive and fixed fragments demonstrated that even populations with low-frequency fragments have a high intrapopulation genetic variability plus a trend for genetic 
differentiation. Shannon's Index and the percentage of polymorphic fragments are genetic parameters successfully employed to estimate the genetic variability of the population (ALMEIDA et al., 2013; GOMES et al., 2011, 2013; JACOMETO et al., 2010; LOPERA-BARRERO et al., 2010; PAULA, 2006).

Table 3. Number of specimens (N), Shannon's Index of genetic diversity (SI) and percentage of polymorphic fragments (PF) for populations (PopA and PopB) of Piapara (L. elongatus) in the HPP São Domingos area.

\begin{tabular}{cccc}
\hline Population & N & SI & PF \\
\hline PopA & 30 & 0.309 & 61.80 \\
PopB & 30 & 0.392 & 71.90 \\
\hline
\end{tabular}

The analysis of molecular variance (AMOVA) between the populations revealed a greater intra-population rather than an inter-population variation. On the other hand, genetic distance and identity rates showed differentiation between the populations (Table 4). Fst and Nm rates showed moderate genetic differentiation (WRIGHT, 1978), with a low number of migrant fish (Table 5). Results demonstrate the formation of two genetically distinct groups, with low genic flow $(\mathrm{Nm}=3.6)$ between the populations, possibly due to the ascending migration impairment of adult specimens, fingerlings and larvae of L. elongatus from upstream to downstream.

Table 4. Analysis of molecular variance (AMOVA), variation source (VS), sum of squares (SS), coefficient of variation $(\mathrm{CV})$, percentage of variation $(\% \mathrm{~V})$, distance (D) and genetic identity (I) for populations (PopA and PopB) of Piapara (L. elongatus) within the HPP São Domingos area.

\begin{tabular}{ccccccc}
\hline Grouping & VS & SS & CV & \%V & D & I \\
\hline \multirow{3}{*}{ PopA x PopB } & BP & 25.483 & 0.70100 & $13.60^{*}$ & 0.089 & 0.915 \\
& WP & 258.300 & 4.45345 & 86.40 & & \\
\cline { 2 - 7 } & Total & 283.783 & 5.15444 & 100 & & \\
\hline
\end{tabular}

$* \mathrm{P}<0.05 . \mathrm{BP}=$ between populations. $\mathrm{WP}=$ within populations.

Table 5. Fst, $\chi^{2}$ test for Fst, genetic differentiation according to Wright (1978) and number of migrants per generation $(\mathrm{Nm})$ for populations (PopA and PopB) of Piapara (L. elongatus) in the HPP São Domingos area.

\begin{tabular}{ccccc}
\hline Grouping & Fst & Wright & $\chi^{2}$ & Nm \\
\hline PopA $\times$ PopB & $0.136^{*}$ & Moderate & 16.32 & 3.60 \\
\hline
\end{tabular}

$* \mathrm{P}<0.05$.

Research by Gomes et al. (2013) and Ramos et al. (2012) demonstrated that physical barriers, such as HPP, affect the genetic composition of populations in the regions upstream and downstream. Current research showed that a natural barrier, such as the Cachoeira Branca, also triggers a genetic differentiation in the populations but does not totally hinder the genic flow between the two. It may be presumed that the construction of the dam impedes the genic flow from the upstream to the downstream section since no descending transposition system is totally efficient. Moreover, lifts (ascending transposition) may be lethal to fish (SIROL; BRITO, 2006).

Research on transposition techniques such as that undertaken by Agostinho et al. (2011) in the HPP on the river Tocantins showed that the fish transposition ladder may be restrictive for migrating (such as L. elongatus) and non-migrating species. According to the above authors, the ladders are deficient in the passage downstream. In fact, all fish caught on the transposition ladders were within an ascending migration (downstream to upstream). It is expected that the same occurs in the São Domingos HPP since it will affect the genic flow previously warranted by the 
waterfall. The installed transposition mechanism must permit a controlled passage for fish so that populations in the downstream section of the dam would not be eliminated, since this population does not have access to the upstream section. It is expected that sub-populations of L. elongatus would be formed in the upstream region since the ascending transposition may provide a genetic imbalance in the upstream populations. According to Marteleto (2015), when a population is fragmented and its size is reduced, endo-crossings between specimens increase, with a decrease in reproduction performance. Consequently, the population becomes more vulnerable to the effects of genic drift, with a decrease in the offspring's adaptability.

Results on genetic variability in current assay may be employed as an initial basis for the genetic distribution of wild populations of L. elongatus and may be an asset in future studies on the implantation of conservation and preservation programs of migrating fish species (for instance, re-populations) impacted by dams. Current analysis showed that dominant markers may be a simple tool to achieve these aims. According to Hilsdorf (2013), the employment of dominant markers to estimate variability is common in fresh water fish and is corroborated by several recent research works in Brazilian native species (ALMEIDA et al., 2013; GOMES et al., 2011, 2013; JACOMETO et al., 2010; LOPERA-BARRERO et al., 2010; RAMOS et al., 2012).

Genetic variability was actually high in each population and revealed differences between the Cachoeira Branca upstream and downstream populations, with low genic flow among the groups' specimens. The transposition ladders of the São Domingos HPP should serve as a controlled fish transposition for the maintenance of genetic variability. Further studies should analyze this differentiation of the populations upstream and downstream the dam.

\section{References}

Agostinho, A. A.; GOMES, L. C.; PeliCiCE, F. M. Ecologia e manejo de recursos pesqueiros em reservatórios do Brasil. Maringá: EDUEM, 2007. 501 p.

AGOSTINHO, A. A.; JÚLIO JÚNIOR, H. F.; GOMES, L. C.; BINI, L. M.; AGOSTINHO, C. S. Composição, abundância e distribuição espaço-temporal da ictiofauna. In: VAZZOLER, A. E. A. M.; AGOSTINHO, A. A.; HAHN, N. S. (Ed.). A planície de inundação do Alto rio Paraná: aspectos físicos, biológicos e socioeconômicos. Maringá: EDUEM, 1997. p. 179-278.

AGOSTINHO, C. S.; PELICICE, F. M.; MARQUES, E. E.; SOARES, A. B.; ALMEIDA, D. A. A. All that goes up must come down? Absence of downstream passage through a fish ladder in a large Amazonian river. Hydrobiology, Springer, v. 675, n. 1, p. 1-12, 2011.

ALMEIDA, F. S. de; LOPES, C. M.; ORSI, M. L.; SIROL, R. N.; SODRÉ, L. M. K. Genetic monitoring by RAPD markers for repopulation programs of Salminus brasiliensis (Pisces, Characiformes). Acta Scientiarum. Animal Sciences, Maringá, v. 35, n. 2, p. 119-126, 2013.

ANDRADE, E. de S. Aspectos da biologia reprodutiva de piapara (Leporinus obtusidens), capturados a jusante da Usina Hidrelétrica do Funil, Perdões/Minas Gerais. 2009. Mestrado (Dissertação em Medicina Veterinária) Universidade Federal de Lavras, Lavras.

BRASIL. Banco de informações de geração da ANEEL. São Paulo: ANNEL, 2015. p. 1-2. Disponível em: http://www.aneel.gov.br/aplicacoes/capacidadebrasil/ capacidadebrasil.cfm>. Acesso em: 20 jul. 2015.

ELETROBRAS-ELETROSUL. $4^{\circ}$ Relatório semestral de andamento dos programas de planos ambientais. Usina Hidroelétrica São Domingos. Florianópolis: EletroBras, 2014. Disponível em: <http://www.eletrosul. gov.br/files/files/Doc.\%20socioambientais\%20UHSD/ UHSD_Relat_Sem_4_set_2014_Volume_I.pdf $>$. Acesso em: 20 jul. 2015.

EXCOFFIER, L.; LAVAL, G.; SCHNEIDER, S. Arlequin (version 3.0): an integrated software package for population genetics data analysis. Evolutionary Bioinformatics Online, Auckland, v. 1, n. 1, p. 47-50, 2005.

EXCOFFIER, L.; SMOUSE, P. E.; QUATTRO, J. M. Analysis of molecular variance inferred from metric distances among DNA haplotypes: application to human mitochondrial DNA restriction data. Genetics, Bethesda, v. 131, n. 2, p. 479-491, 1992. 
FONTES, R. C. L. Avaliação temporal e espacial da comunidade de peixes no canal de fuga da usina hidrelétrica de Três Marias, Rio São Francisco, MG. 2011. Dissertação (Mestrado em Ecologia Aplicada) Universidade Federal de Lavras, Lavras.

GASQUES, L. S.; BELONI, K. P.; OLIVEIRA, J. R. Os marcadores moleculares em peixes e suas aplicações em publicações da base de dados do Scielo. Arquivo de Ciências Veterinárias e Zoologia UNIPAR, Umuarama, v. 16, n. 1, p. 47-50, 2013.

GOMES, P. C.; LOPERA-BARRERO, N. M.; VARGAS, L.; STREIT JR, D. P.; POVH, J. A.; SIROL, R. N.; RIBEIRO, R. P. Genetic diversity of Salminus brasiliensis (Characiformes: Characidae) collected in the passage ladder of the Canoas I hydropower plant in the Paranapanema River, Brazil. Semina: Ciências Agrárias, Londrina, v. 34, n. 3, p. 1421-1432, 2013.

GOMES, P. C.; RIBEIRO, R. P.; SIROL, R. N.; LOPERABARRETO, N. M.; MOREIRA, H. L. M.; JAYME POHV, J. A.; MANGOLIN, C. A.; VARGAS, L.; JACOMETO, C. B.; STREIT JÚNIOR, D. P. Diversidade genética de dourado utilizado em programas de repovoamento no rio Paranapanema. Pesquisa Agropecuária Brasileira, Brasília, v. 46, n. 2, p. 167-176, 2011.

HILSDORF, A. W. S. Marcadores moleculares e a caracterização dos recursos genéticos de peixes: desenvolvimento sustentável da aquicultura e da pesca de espécies nativas de água doce no Brasil. 2013. Tese (Livre Docência). Universidade de São Paulo, Pirassununga.

JACOMETO, C.B.; BARRERO, N.M. L.; RODRIGUEZRODRIGUES, M. D. P.; GOMES, P. C.; PAYH, J. A.; STREIT JÚNIOR, D. P.; VARGAS, L.; RESENDE, E. K.; RIBEIRO, R. P. Variabilidade genética em tambaquis (Teleostei: Characidae) de diferentes regiões do Brasil. Pesquisa Agropecuária Brasileira, Brasília, v. 45, n. 5, p. 481-487, 2010.

LIMA, M. A. Desenvolvimento local e políticas públicas para comunidades atingidas por barragens: ocaso da Usina Hidrelétrica do Funil. 2015. Dissertação (Mestrado em Política Pública) - Universidade Federal de Lavras, Lavras.

LOPERA-BARRERO, N. M. Conservation of Brycon orbignyanus natural populations and stocks for their reproductive, genetic, environmental sustainability: a model for species threatened with extinction. Ciencia e Investigación Agrária, Santiago, v. 36, n. 2, p. 191-208, 2009.
LOPERA-BARRERO, N. M.; POVH, J. A.; RIBEIRO, R. P.; GOMES, P. C.; JACOMETO, C. B.; LOPES, T. S. Comparación de protocolos de extracción de ADN con muestras de aleta y larva de peces: extracción modificada con cloruro de sodio. Ciencia e Investigación Agraria, Santiago, v. 35, n. 1, p. 76-86, 2008.

LOPERA-BARRERO, N. M.; VARGAS, L.; SIROL, R. N.; RIBEIRO, R. P.; POVH, J. A.; MANGOLIN, C. A. Caracterização genética de Brycon orbignyanus utilizando o sistema seminatural. Arquivo Brasileiro de Medicina Veterinária e Zootecnia, Belo Horizonte, v. 62, n. 1, p. 184-191, 2010.

LUIZ, E. A.; GOMES, L. C.; AGOSTinho, A. A.; BULLA, C. K. Influência de processos locais e regionais nas assembleias de peixes em reservatórios do Estado do Paraná, Brasil. Acta Scientiarum, Maringá, v. 25, n. 1, p. 107-114, 2003.

MARTELETO, F. M. Os efeitos da introdução de barreiras artificiais em rios sobre a genética populacional em peixes. 2015. Tese (Doutorado em Biologia) Universidade Federal do Paraná, Curitiba.

MILLER, M. P. Tools for population genetic analyses (TFPGA): a Windows program for the analysis of allozyme and molecular population genetic data. Version 1.3. Flagstaff: Northern Arizona University, 1997. 33 p.

NEI, M. Estimation of average heterozygosity and genetic distance from a small number of individuals. Genetics, Bethesda, v. 89, n. 3, p. 583-590, 1978.

PAUlA, F. M. Diversidade genética de Prochilodus lineatus (Pisces Characiformes) das escadas de transposição de peixes das usinas hidroelétricas do complexo Canoas - Rio Paranapanema. 2006. Mestrado (Dissertação em Genética e Biologia Molecular) Universidade Estadual de Londrina, Londrina.

POVH, J. A.; LOPERA BARRERO, N. M.; RIBEIRO, R. P.; LUPCHINSKI JÚNIOR, E.; GOMES, P. C.; LOPES, T. S. Monitoreo genético de programas de repoblamiento de peces mediante marcadores moleculares. Ciencia e Investigación Agraria, Santiago, v. 35, n. 1, p. 25-35, 2008.

RAMOS, J. V. B.; SODRÉ, L. M. K.; ORSI, M. L.; ALMEIDA, F. S. D. Genetic diversity of the species Leporinus elongatus (Teleostei: Characiformes) in the Canoas Complex-Paranapanema River. Neotropical Ichthyology, Maringá, v. 10, n. 4, p. 821-828, 2012.

RAYMOND, M.; ROUSSET, F. An exact test for population differentiation. Evolution, New York, v. 49, n. 6, p. 1280-1283, 1995. 
SIROL, R. N.; BRITTO, S. G. Conservação e manejo da ictiofauna: repovoamento. In: NOGUEIRA, M. G.; HENRY, R.; JORCIN, A. (Ed.). Ecologia de reservatórios: impactos potenciais, ações de manejo e sistemas em cascata. São Carlos: Rima, 2006. p. 275-284.

SUZUKI, F. M. Estudo do comportamento de peixes no canal de fuga da usina hidrelétrica de Três Marias utilizando telemetria acústica. 2014. Tese (Doutorado em Ecologia Aplicada - Ecologia e Conservação de Recursos em Paisagens Fragmentadas e Agrossistemas) - Universidade Federal de Lavras, Lavras.

WEIR, B. S.; COCKERHAM, C. C. Estimating F statistics for the analysis of population structure. Evolution, New York, v. 38, n. 6, p. 1358-1370, 1984.
WILLIAMS, J. G. K.; RAFALSKI, J. A.; KUBELIK, A. R.; LIVAK, K. J.; TINGEY, S. V. DNA polymorphism amplified by arbitrary primers are useful as genetic markers. Nucleic Acids Research, Oxford v. 18, n. 22, p. 6531-6535, 1990.

WORKMAN, P. L.; NISWANDER, J. D. Population studies on southwestern Indian tribes. II. Local genetic differentiation in the Papago. American Journal of Human Genetic, Chicago, v. 22, n. 1, p. 24-49, 1970.

WRIGHT, S. Evolution and the genetics of populations. Chicago: University of Chicago, 1978. 580 p.

YEH, F. C.; BOYLE, T. Y. Z.; XIYAN, J. M. PopGene Version 1.31: Microsoft Window based freeware for population genetic analysis. Alberta: University of Alberta and Center for International Forestry Research, 1999. 29 p. 
